\title{
Rorty's Philosophy of Education: Between Orthodoxy and Vulgar Relativism
}

Rhoderick John S. Abellanosa

$\mathrm{R}$ ichard Rorty once said that the search for objective truth is [not] the search for correspondence to reality [instead] it is a search for the widest possible inter-subjective agreement. ${ }^{1}$ This statement, among many others, is a reason why some of his commentators consider his philosophy to be relativist, although it is safe to say that this observation may be due to the lack of an informed understanding of relativism, its epistemological underpinnings and nuances. To totally label Rorty as a relativist and nothing else is, I believe, more of an oversimplification of his not so uncomplicated thoughts; labels which if not well nuanced or contextualized, would surely fall short of capturing the expanse of the philosopher's fundamental contentions. ${ }^{2}$

Yet the concern over relativism's effects in the practical dimensions of life is understandable. This is especially true if the said-to-be kind of relativism is espoused by a philosopher whose influence has started to sink-in to the different fields of the contemporary intellectual world. Rorty is, perhaps, a good example of this, for without doubt his philosophy (i.e. particularly his epistemology) has arguably shaped the currents of the philosophy of education.

Thus, this paper seeks to develop a reflexive-analysis of Rorty's philosophy of education, most particularly those that he has articulated in the essay "Hermeneutics, General Studies, and Teaching."3 The said essay reflects

1 Richard Rorty, "Does Academic Freedom have Philosophical Presuppositions; Academic Freedom and the Furture of the University," in Academe (November-December 1994), 52.

2 Rorty would not even admit the label relativist. In Philosophy and Social Hope, he makes use of the term "so-called relativists". Apparently, the usage of the term "so-called" highlights that the charge of relativism is not an admitted or acknowledged categorization by Rorty, in fact, it rebounds to those who would prefer or insist to call the American pragmatist as such. Substantiating this using the philosopher's own words, "[w]e so-called relativists refuse, predictably, to admit that we are enemies of reason and common sense. We say that we are only criticizing some antiquated, specifically philosophical, dogmas. But, of course, what we call dogmas are exactly what our opponents call common sense." Philosophy of Social Hope (London: Penguin, 1996), xvii.

${ }^{3}$ For brevity sake, the said essay may be cited in this article as HGST. It is compiled together with many other philosophical essays on education by Steven M. Cahn of the Graduate 
the complexity of his thought. I believe it is not the best work to read if the goal is to initially understand the "essential Rorty". Nevertheless, it is a wellcrafted essay and a good piece for a student of philosophy of education to be introduced in a more direct way to some basic themes of Rorty's perspectives on perennial issues in education like truth and its nature, the curriculum, etc. Apparently, Rorty's philosophy is a serious indictment to the existing classical philosophical viewpoints on education, some of which have been treated de facto as dogmatic statements by some camps in the tradition. ${ }^{4}$

\section{Philosophy, Knowledge, and Education}

The best entry point to understand any philosophy of education is to know and familiarize the gist of the philosopher's philosophy. This modest attempt to do the same with Rorty's philosophy of education is not an exception. Let us begin therefore, this enterprise of knowing his educational philosophy, with a relatively brief discussion of his philosophy.

In Philosophy and the Mirror of Nature, Rorty says that:

P]hilosophy is not a name for a discipline which confronts permanent issues, and unfortunately keeps mistaking them, or attacking them with clumsy dialectical [i]nstruments. Rather, it is a cultural genre, a 'voice in the conversation of mankind ... which centers on one topic rather than another at some given time not by dialectical necessity but as a result of various things happening elsewhere in the conversation... or of individual men of genius who think of something new ... or perhaps of the resultant of several forces. ${ }^{, 5}$

Philosophy cannot and should not claim to possess unquestionable methods. Neither should it claim that its object of study is a non-time-bound reality: unchanging or eternal. As regards methodology, Rorty seems to contend that philosophy cannot account for everything that is fundamental in all genres of human thinking. Political Science for example is philosophical due to the fact that it developed from the positivist tradition. As a social

School of The City University of New York. See Classic and Contemporary Readings in Philosophy of Education (New York: McGraw-Hill Companies, 1997), 522-536.

4 To formally set the parameters of the discussion, this paper does not aim at expounding the individual major writings of Rorty (e.g. Philosophy and the Mirror of Nature); primarily, limit in space prevents such. It does not mean however that we have relegated to the periphery the many important works of the American philosopher; more than certain, the major works are important. It is just that, among others and for pragmatic reasons, the objective of this endeavor prevents the necessary length and breadth - to provide a fairly sufficient space for a substantial discussion of the far reaching themes of the focused philosopher's several works.

5 Richard Rorty, Philosophy and the Mirror of Nature (New Jersey: Princeton University Press, 1979), 264. 
science, it comes from the grand project of the Enlightenment where science was exalted. It therefore, has a specific epistemology and a political ontology in all analyses or readings of political life. In this sense, political science is presupposed by philosophical principles (e.g. libertarianism, democracy, Marxism); at its very core, political science is a positivist and empirical political philosophy.

The above explanation on philosophy in relation to political science or any other discipline for that matter would only be acceptable however if there are no arguments anymore as to the nature of philosophy. But the "very nature" of philosophy is what Rorty would like to argue against. Philosophy is not and cannot be what its defenders think of it that is, an autonomous discipline or that sort of "technical or professional philosophy." We cannot conceive of the mind as a mirror that can reflect, whether clearly or not so clearly, the reality that is outside of it. More so, it is not possible to think of philosophy as beholden to the principle adequatio et rei intellectus (adequation between the intellect and the thing). Rorty seems to have vindicated Heidegger in the belief that although we have witnessed through the centuries the battle of giants in philosophy (e.g. Plato v. Aristotle, Empiricism v. Rationalism, etc.), the most fundamental question has been long forgotten.

Rorty's sources of inspiration or influence in thinking are revealed in his Philosophy and the Mirror of Nature; he calls them heroes: Wittgenstein, Heidegger and Dewey. ${ }^{8}$ A glimpse into the philosophical ideas of the said heroes would reveal that Rorty after all has not been alone, to some extent, in his views and sentiments on philosophy and philosophizing. Tartaglia in his book Rorty and the Mirror of Nature - explains that "other than their being the most romantic, the farthest out, and the most prophetic" - they "are all opposed to representational conceptions of the mind and knowledge, that is, to

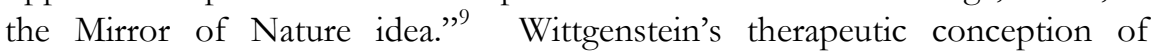

${ }^{6}$ James Tartaglia, Rorty and the Mirror of Nature (London: Routledge, 2007), 3.

${ }^{7}$ In Being and Time, Heidegger says, "This question has today been forgotten. Even though in our time we deem it progressive to give our approval to 'metaphysics' again . . . Yet the question we are touching upon is not just any question. It is one which provided a stimulus for the researches of Plato and Aristotle, only to subside from the on as a theme for actual investigation. What these two men achieved was to persist through many alterations and 'retouchings' down to the logic of Hegel. And what they wrested with the utmost intellectual effort from the phenomena, fragmentary and incipient though it was, has long since become trivialized." Being and Time, trans. by John Macquarrie and Edward Robinson (New York: Harper and Row, 1962), 2.

Here, I am not suggesting that Rorty completely follows Heidegger. On the other hand it is not my contention also that Heidegger's philosophical problem is the same with that of Rorty. These beside the point, my usage of the word "vindicate" in the statement Rorty "has vindicated" Heidegger means that there is a parallelism between how the two looked at philosophy. In my view, they both understand philosophy as a constructed system that has accumulated a set of propositions that constitutes its canonized problems. The clearly significant difference of Heidegger from Rorty is the former's fundamental concern, i.e. Seinsfrage [the fundamental question concerning Being].

${ }^{8}$ Tartaglia, op cit., 19

${ }^{9}$ Ibid. 
philosophy is his contribution and relevance to Rorty. One can see an evidence of Wittgensteinian influence in Rorty's position that philosophy should dissolve rather than solve problems; a position that calls for the interrogation of the conviction that philosophy has the capacity and role to essentialize things. On the other hand, Heidegger's place in Rorty's philosophy is the former's "desctruction" in Sein und Zeit, which is what the latter employs in his method of historical deconstruction; something which is evident in his view of philosophy in general and epistemology in particular. Then the third hero is Dewey, whose contribution and influence on Rorty is pragmatism. In his debate with Jurgen Habermas, and Leszek Kolakowski on the challenge of relativism, the transcript of which was published as a book Debating the State of Philosophy Rorty says:

The philosopher I most admire, and of whom I should most like to think of myself as a disciple, is John Dewey. Dewey was one of the founders of American pragmatism. He was a thinker who spent sixty years trying to get us out from under the thrall of Plato and Kant. ${ }^{10}$

Rorty's "Hermeneutics, General Studies, and Teaching" is an attempt to address the problem of "how education might be conceived if one starts from the Nietzschean rather than the Platonic assumptions."11 This question suggests that a philosophy of education may not be a continuous or uninterrupted narrative like the common presentation of the history of philosophy. Both Plato and Nietzsche are concerned with the search for truth. The former found it in the World of Forms while the latter believes that it is in the Will to Power. Should it follow that just because Plato lived centuries earlier than Nietzsche, philosophy should begin with him? At the onset of the essay, Rorty points out that "any philosophy professor asked to talk about education can be expected to begin by noting that the word education means "like bringing out" and then talking about Plato's recollection. Thus, philosophy (and philosophy of education specifically) in Plato stands on the ground of an ultimate reality (the world of forms) and that the human mind possesses something which is "like that reality" - in the words of Rorty, "there is a natural attunement between Reason and the nature of things." This is something that has been deeply embedded in the centuries-tradition of Western philosophy, more so up to Kant who hoped to provide philosophy a "secure path of science."12 Opinions not so favorable to Rorty's philosophy have developed as a consequence of his anti-Platonic notion of truth; his antiPlatonist hermeneutics or endeavor has been denounced by some scholars as

${ }^{10}$ Josef Niznik and John T. Sanders, Debating the State of Philosophy: Habermas, Rorty and Kolakowski (Westport, Connecticut: Praeger), 32.

11 Steven M Cahn, Classic and Contemporary Readings in Philosophy of Education (New York: McGraw-Hill Companies, 1997), 523.

12 Tartaglia, op cit., 2. 
one that espouses relativism (vulgar relativism for that matter). ${ }^{13}$ The reactions against Rorty's philosophy mostly generate from the fear that without anything objective, everything ends up possible and/or allowable. If all things are allowable, and that all concepts are in no way objective, what is the significance of education? Why study and teach things that after all are fluid or changeable?

In response to the objection discussed above, the American pragmatist draws insights from Gadamer and Dewey, and builds a formidable argument on the foundations of their philosophies, without compromising his view on truth as non-objective (and merely a product of inter-subjective agreement) and the (still) uncontested necessity of education within and for a community. But why Dewey and Gadamer? The simplest answer to the question is that there is a point of convergence between Dewey and Gadamer and that is antifoundationalism. Dewey is a pragmatist, and as one he does not subscribe to the belief in an objective or unchangeable truth. ${ }^{14}$ Gadamer on the other hand developed his hermeneutics as interpretation which cannot be subjected to any rigid and frozen set of rules. In the words of Rorty himself:

I want to offer an account of the common elements in Gadamer and Dewey's thought which enable them to defend themselves against such charges. I shall argue that both men put in place of Reason - the Platonic organ for detecting truth - is a sense of tradition, of community, of human solidarity. ${ }^{15}$

At this juncture let us briefly acquaint ourselves with the general overview of Gadamer's hermeneutics and Dewey's pragmatism. We shall then return to Rorty's synthesis of their points of convergence and try to figure out how his appropriation of both has successfully served as a defense against his critiques.

${ }^{13}$ One of those who openly labels Rorty as relativist is Charles Taylor. According to Taylor, " . . . Rorty's whole coping with foundationalism, realism, antirealism, and such-like issues cannot but exacerbate his vulnerabilities to this kind of capture. Essentially Rorty's view resembles certain kinds of relativisms and nonrealisms ..." Charles Taylor, "Rorty and Philosophy" in Charles Guignon and James Hiley eds., Richard Rorty (Cambridge: Cambridge University Press, 2003), 171.

Habermas, on the other hand, labels Rorty's neopragmatism as a sophisticated version of present historicism. In Habermas' view, the Rortian pragmatism continues as a third phase of the dialectics of anti-platonism. Habermas asks, "Does Rorty succeed in finishing with the philosophical language game as such? While pretending to do so, he seems only to start another round of the same game. If this observation is correct, the assumption about the inclusive nature of world-disclosing languages, the founding of antifoundationalism, is up for reconsideration." Josef Niznik and John T. Sanders, op cit., 18-19.

14 This statement however is not a claim that Rorty is in no way different from Dewey. Guignon and Hiley for example believe that Rorty breaks from Dewey in the belief that science has a privileged status among language games. One can see evidences of this contention in his essay "Hermeneutics, General Studies, and Teaching" in Classic and Contemporary Reading in Philosophy of Education.

${ }^{15}$ Rorty, HGST, 254. 


\section{2}

\section{RORTY'S PHILOSOPHY OF EDUCATION}

\section{Hans-Georg Gadamer and Hermeneutics}

From a Gadamerian point of view, philosophy is hermeneutics - it is a search for truth, it cannot be a search for an objective truth. To understand something means to understand it within the context of the thing's historicity. What is sought to be understood may be an event or a person, but one thing is sure: the process is hermeneutic and not any application of a rigid analysis of an object coming from an unquestionable ontology. According to Quito, "truth eludes the methodical individual; method retards and subverts truth. Truth therefore can be reached not methodically but dialectically." With utmost clarity, he has stressed his aim in coming up with a hermeneutic enterprise:

I did not intend to produce an art or a technique in the manner of earlier hermeneutics. I did not wish to elaborate a system or to describe, let alone, direct the methodical procedure of the human sciences. Nor was it my aim to investigate the theoretical foundation of work in these fields in order to put my findings to practical ends ... my real concern was and is philosophic: not what we do or what we ought to do, but what happens to us over and above our wanting and doing. ${ }^{16}$

In explaining his point, Gadamer says that there are four humanistic concepts in hermeneutics: Bildung, senus communis, taste, and judgment.

Bildung (culture) - has the connotation of "natural form" but in its most profound sense, it refers to the proper human way of developing one's natural talents and capacities. Thus, the more preferred equivalent for Bildung is formation. Formatio as Bildung however is not the same with formation that is the non-active undergoing of a process in the hands of the formator. It is according to one commentator "in the Hegelian sense, the rising to the universal" 17 which requires leaving behind one's particularity, overcoming one's limited perspective, and assuming the widest horizon possible. If Bildung, as Gadamer says, is an avenue to truth, hence, constitutive of any endeavor at understanding a text or an object of interpretation, then one should go beyond the self in order to enter the other. In this sense, hermeneutics should necessarily involve the "entire history in its interpretation." According to Emerita Quito, "every single individual who want to raise himself out of his natural being to the spiritual world would have to make the, customs and institutions of a people his very own.",18

16 Hans-Georg Gadamer, Truth and Method (London: Sheed and Ward, 1979), xvii.

17 Ibid., 13. Also cf. Dennis C. Villarojo, The Ontological Conditions of Understanding: A Study of the Hermeneutics of Hans-Georg Gadamer in the Light of the Encyclical Fides et Ratio (Rome: Pontifical University of the Holy Cross, 2001), 112.

${ }^{18}$ Emerita Quito, Philosophers of Hermeneutics (Manila: De La Salle Press, 1990), 54. 
Sensus communis - is not "common sense" as few interpreters understand it. Instead, it is that sense of what is right and the common good that is to be found in all men. Such is acquired through living in a community and is determined by its structures and aims. Knowledge in this light, is neither acquired through method, nor through the knowledge of the universals; rather, it is learned from the insights of the traditions of the community which expresses its "collective wisdom." Knowledge is therefore acquired by living in a community, and not just any living but involvement, passionate participation if we may; and not just any community but concrete community also. In the words of Emerita Quito, "sensus communis is the virtue of social intercourse."19

Judgement - is what enables the individual to discriminate among events. It is more than the act of the intellect, which makes decisions based on objective criteria. According to Weinshimer in his commentary on Gadamer's hermeneutics, "judgment is like a common sense in that it . . . cannot be logically certified." $" 20$ It is like an act of prudence. In Gadamer's own words, "[i]t cannot be taught in the abstract but only practiced from case to case, and is therefore more an ability like a sense. It is something that cannot be learned, because no demonstration from concepts can guide the application of the rules." 21 Judgment is significant in hermeneutics because the process of understanding a "spirit or life science" cannot be insured by stringent and frozen rules as these rules may just destroy the very "life" that one seeks to understand and appreciate.

Taste - can only be understood in relation to the three other humanistic concepts. There is no exact definition of taste; no accounting of it or any general criteria. ${ }^{22}$ It may be understood as certainty in judgment, hence the perfection of judgment. ${ }^{23}$ But taste cannot be such also if it does not come from the community, so that it involves the whole. The interpretation of the whole is not possible without any taste of the whole - a holistic assessment of the entire community or event that comes from the community. Taste therefore cannot be such apart from the Bildung. It is on the other hand, characteristically in close affinity with sensus communis and judgment.

Hermeneutic reflection is necessary when we deal with human beings whose experiences cannot always be categorized, labeled and artificially studied. Quito (1990) commenting on the hermeneutics of Gadamer, says that Gadamer's hermeneutics is this openness to the other. The German philosopher's method is actually inspired by Martin Heidegger, who believes that man is not just an animal rationale but more than such, a Dasein. Dasein is capable of asking the very question of his there-being. Dasein's horizon is Being and the horizon of Being is Time. The existential analytic of Dasein

19 Ibid., 55

20 Joel Weinshimer, Gadamer's Hermeneutics: A Reading of Truth and Method (New Haven: Yale University Press, 1985), 75.

21 Gadamer, op cit., 31.

22 Quito, op cit., 57.

23 Villarojo, op cit., 118-119. 


\section{4}

\section{RORTY'S PHILOSOPHY OF EDUCATION}

therefore necessarily involves the explication of his historicity and temporality. ${ }^{24}$

Drawing from the insights of Gadamer, Rorty explains one of his themes in the essay HGST - "education [is] aiming at a sense of human community, and of this community as foundationless, supported neither by sciences nor by history, but only by hope." 25 This statement can be understood better if one goes back to the four humanistic hermeneutical concepts of Gadamer, in the context of which education may be understood as a hermeneutic enterprise.

From Gadamer, we now proceed to Dewey, whose philosophy is also used by Rorty as a framework in his philosophy of education. Here it is argued that the limits of Gadamer's hermeneutics are complimented by Dewey's pragmatism. While Gadamer has provided an anti-Platonist framework, yet its privileging of play over method is at the same time the reason for its inability to be relevant to those who are in search for a pragmatic philosophy. Apparently, the point being driven here is while it is important to avoid essentializations, as in the case of Gadamer's hermeneutics, nevertheless this does not mean that we should not hold on to anything clear and instead consign to mysteries and conundrums. On this note, we turn our focus to Dewey's pragmatism.

\section{John Dewey and Pragmatism}

Dewey considers the philosophies since Plato as problematic. For him, philosophers were confused between the "nature of knowledge" and the "function of knowledge." 26 A philosophy that myopically preoccupies itself with the question on the nature of knowledge is a "spectator philosophy" and devoid of experience, which is what should enrich philosophy - in fact it is what philosophy should be. As a pragmatist Dewey has taken by heart "the refusal to accept the correspondence theory of truth and the idea that true beliefs are accurate representations of reality." 27

In the light of the Deweyan notion of knowledge, and the prescription that has been generated from it - on how education as a process must be done, it is important to highlight that values do not have any ontological source. The gradations of relevance we place upon things are not grounded on anything metaphysical; hence, we cannot essentialize values. The mind discovers values in the same way as it discovers facts. Thus, for Dewey, the scientific method is

24 According to Heidegger, "In analysing the hitoricality of Dasein we shall try to show that this entity is not 'temporal' because 'it stands in history,' but that, on the contrary, it exists historically and can so exist only because it is temporal in the very basis of its Being." Being and Time, 428 .

25 Rorty, HGST, 530.

26 Samuel Enoch Stumpf, Socrates to Sartre: A History of Philosophy, 6 ${ }^{\text {th }}$ ed. (Boston: McGraw Hill, 1999), 366.

27 Richard Rorty, Philosophy as Cultural Politics: Philosophical Papers, vol. 4 (Cambridge: Cambridge University Press, 2007), 105. 
very important as it consists the "observation, reflection, and testing . . . deliberately adopted to secure a settled, assured subject matter." As Dewey said in his Democracy and Education:

Processes of instruction are unified in the degree in which they centre in the production of good habits of thinking. While we may speak, without error, of the method of thought, the important thing is that thinking is the method of an educative experience. The essentials of method are therefore identical with the essentials of thinking. ${ }^{28}$

A critique hurled against pragmatism is that it does not have any organ for truth. ${ }^{29}$ As such it is an anti-thesis to the classical notion of truth, where there is a subject and an object, and the former has the capability of grasping an objective truth about the other. Does it mean to say therefore that humanity has to succumb to what is exactly the opposite of what the erstwhile system of thought has established?

Religious instruction can be cited here as an example. Why would American universities still offer Religious Studies in their Divinity Schools if it has been obviously known that the once-upon-a-time metaphysical foundations of the proofs for a Supreme Being's existence - are flawed? Coming from Dewey, a possible answer to this question is that, it is not so much about the philosophical certainty or the soundness of the metaphysical truth, but in the fact that still religious communities contribute something to society, and these contributions remain to be part of human culture. It's not so much about the universality or the universalizability of the ethics subscribed to by a religious sect, but in what this specific kind of ethics may offer to help improve society. As what Dewey says in Democracy and Education:

Hence, once more, the need of a measure for the worth of any given mode of social life. In seeking this measure, we should avoid two extremes. We cannot set up, out of our heads, something we regard as an ideal society. We must base our conception upon societies which actually exist, in order to have any assurance that our ideal is a practicable one. But, as we have just seen, the ideal cannot simply repeat the traits which are actually found. The problem is to extract the desirable traits of forms of community life which actually exist, and employ them to criticize undesirable features and suggest improvement. ${ }^{30}$

\footnotetext{
28 As cited by Rorty in HGST, 527.

${ }^{29}$ Ibid.

30 John Dewey, "Democracy and Education," in Steven M. Chan, Classic and Contemporary Reading in Philosophy of Education, 289.
} 
Another objection to pragmatism's dismissal of truth within the context of truth as adequation comes from the argument that a realist epistemology stems, ultimately, from common sense! For example, should Aristotle's characterization of man as a political animal - an essentialization of man if it is evident that the in every persons there is a disposition towards politics. Ergo, isn't this a vindication of the ontologically laden statement "man by nature is a political animal?" Why call such an Aristotelian premise an essentialization of man, when it is simply a set of words that speaks of a universal human experience?

To this objection, Rorty has this reply:

Common sense distinguishes between the apparent color of a thing and its real color, between the apparent motions of heavenly bodies and their real motions, between non-dairy creamer and real cream, and between fake Rolexes and real ones. But only those who have studied philosophy ask whether real Rolexes are really real. $^{31}$

Rorty's distaste for essentialism typically evidences the Deweyan influence. Dewey's distinction, for example, between the nature and knowledge and the function of knowledge is evident a central problem in Rorty's view of philosophy, where he considers the discipline, not as the erstwhile metaphysical queen of the sciences, thus the value of philosophy is not in its capacity to tell us the answers to the ultimate questions about the world, but in the very fact that it is a dialogue and dialogue is a necessity among humans and their community. In the philosopher's own words, "philosophy is not a name for a discipline which confronts permanent issues, and unfortunately keeps mistaking them, or attacking them with clumsy dialectical Instruments. Rather, it is a cultural genre. 'a voice in the conversation of mankind'., 32 This brings the discussion back to Dewey whose understanding of truth is not essentialist but pragmatic.

\section{Hermeneutics, Pragmatism, and Rorty's Philosophy of Education}

Drawing from the thoughts and insights of Gadamer and Dewey, Rorty has come up with a philosophy that is a hybrid of the well-mixed chemistry of Gadamerian hermeneutics and Deweyan pragmatism. Thus, his description of learning in one of the essays is as follows:

\footnotetext{
${ }^{31}$ Rorty, Philosophy as Cultural Politics, 105.

32 Rorty, Philosophy and the Mirror of Nature, 264.
} 
Learning is not a process of helping us to get in touch with something non-human called Truth or Reality (other-worldly, objective, ultimate, unchanging) rather it is what keeps us in touch with our potentialities. ${ }^{33}$

Gadamer's hermeneutics as articulated in his sensus communis, as well as Dewey's pragmatism, both support the view that truth/true assertions are not anchored on some absolute and other-worldly reality, but are simply successful moves in the social practice of what Wittgenstein calls a language-game. Rorty argues that truth is linguistically conditioned, and as such, what may be called by some as objective truth is nothing but a true statement in a certain milieu or cultural context. As what he says of this topic in Contingency, Irony, and Solidarity, "truth is a property of sentences, since sentences are dependent for their existence upon vocabularies, and since vocabularies are made by human beings, so are truths." 34 As Guignon and Hiley remark "vocabulary or language" is the "pivotal concept" of Rorty's version of pragmatism. ${ }^{35}$

The validity of his contention could only be tested if the most common objections against it would be discussed. As in a litmus test, where the nature of a substance is known by the very color it reveals, the pragmatic approach to truth could be better understood if what the critics say of it, would be examined from all angles. The two objections against Rorty's notion of truth as an output of "hermeneutics and pragmatism" are the "argument from moral confrontation" and the "argument from moral evil." Such objections are basically the same problems raised against the hermeneutic and pragmatic philosophies of Gadamer and Dewey respectively. What best summarizes the objections against Rorty is the question, if there is no objective truth then how come there are certain things or experiences universally shared by humanity? In HGST, Rorty specifically identifies this universally shared experience, namely "perceptual confrontation" and "moral evil."

The first argument is based on perceptual confrontation, which basically contends that there is human experience, and it is replete with facts that are universal, meaning to say, they are not just peculiar to one person. Expressed interrogatively, why should we argue against a truth arrived at inductively or against a true statement in the face of a clear and present perception? Simply or pejoratively put, why go around and complicate what is obvious? To this kind of objection, Rorty has this reply, "the paradigm case of truth is the one in which our beliefs are refuted by experience - where, for example, the negative result of a crucial experiment explodes a theoretical edifice. Hard, objective, truth is typified by the brute factuality of that disconforming observation." 36 Furthermore truth is not a matter of Press, 1989), 5

33 Rorty, HGST, 525

34 Richard Rorty, Contingency, Irony and Solidarity (New York: Cambridge University

${ }_{35}$ Guignon and Hiley, Richard Rorty, 14.

${ }^{36}$ Rorty, HGST, 525. 
correspondence. Coming from Heidegger, the American pragmatist argues that one should not confuse correctness with truth because the two are not the same. ${ }^{37}$ Within the context of Rorty's philosophy, the pragmatist and the hermeneuticist join in saying that confrontation with perception is not an illustration of the nature of truth.

The second argument against Rorty's notion of truth is the reality of moral evil. Using Hitler and Stalin as examples, Rorty poses the argument that if there is no objective truth, the two dictators would be justified in their evil acts, for the simple reason that they can create some definitions and construct - their own language games in order to support and legitimize their political agenda. The immediate response to the second objection is that there is no question that there are moral acts, in like manner there are immoral acts. This premise is based on a certain standard of morality, the validity of which comes from a moral tradition; even morality therefore is a product of the community's consensus, which is linguistically conditioned. To oppose an evil is a moral virtue, but the certainty that is supposed to ground or support such opposition is not; it is a non-sequitor to use the need to oppose evil in proving that there is an existence of objective value/s. ${ }^{38}$

In this light, it can be said as a matter of initial synthesis that education is not a process of recollecting some kind of an objective value or absolute truth, say one that exists in the world of forms. Rather, it is the process of inventing something which will improve (Dewey $\rightarrow$ pragmatic) our "tradition" (Gadamer $\rightarrow$ hermeneutics), i.e. "what we have been told."

\section{Humanistic and Scientific Education: The Rortian Perspective}

In HGST, Rorty seeks to address the question of what educational apparatus should be relied upon in order to provide a process of understanding that is neither dogmatic or Platonic nor vulgar relativism. In his view, both the humanistic and scientific dimensions of education have important roles to play in the balancing of the educational process. For one, the humanities (as it was first conceived during the renaissance) and science (enlightenment) were movements that envisioned at emancipating man from authority; they started as revolts against authority. ${ }^{39}$

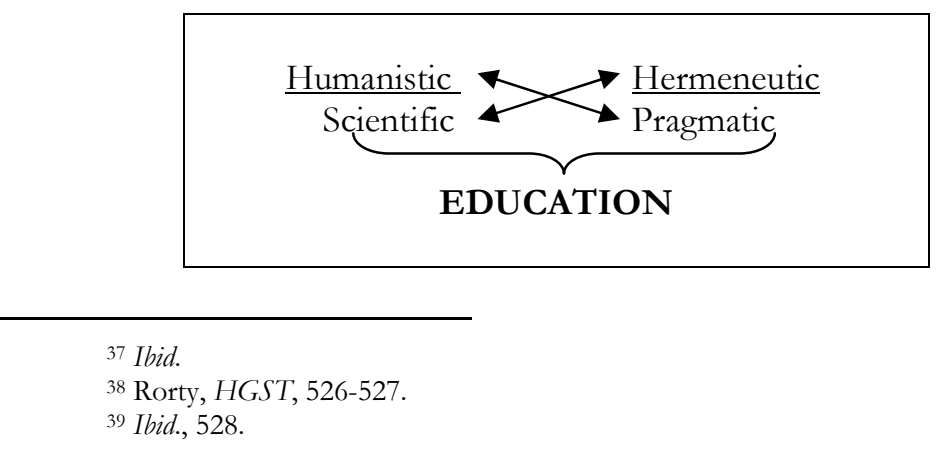


Liberation is the process of removing any attempt of capturing or imprisoning reality with a single vocabulary. Coming from Rorty, it may be argued that a genuine liberal education is not just a reaction as limited as humanism during the enlightenment, or like that of the scientific enlightenment that heralded positivism. Again, using the liberative values of both humanism and scientific education, he came up with a hybrid concept of education, which is a continuum of "successive attempts to create a sense of communal purpose." 40 In the philosopher's own words:

From the pragmatic and hermeneutic point of view, both "the scientific method" and "the Great books" are shibboleths. There is no such thing as "the scientific method outside of moral virtues - willingness to accept experimental disconfirmation, willingness to listen to alternative theories, willingness to scrap an old paradigm and begin again with a new. ${ }^{41}$

But the set of "moral of virtues" Rorty is talking about is not the same with the morals Aquinas speaks of in his ethical system, which is based on Natural Law, and not even Kant's categorical imperative. A morality based on the/an absolute is beside the point, because "Truth is not everywhere the same". It is not everywhere the same because language is not everywhere the same and, human existence is essentially "linguistic" and "historical."42

Is Rorty's philosophy, which speaks of hermeneutics and pragmatism as philosophies that stand beside each other and in constant dialogic, a synthesis in the Hegelian sense of both philosophical camps? My answer is in the negative, and I argue for this position because to say that it is a synthesis in the Hegelian sense means that Rorty has come up with a new method and thereby suggested to displace or replace the old one which is not the case. To further see the relevance of Rorty's philosophy, it is necessary to locate his context, and that is the strongly pragmatic tradition of America (whose pragmatism ends up in the forms of individualism and materialism; to add, in the most pejorative senses of the terms). This is what our philosopher tries to say in his work Consequences of Pragmatism:

So Pragmatists see the Platonic tradition as having outlived its usefulness. This does not mean that they a new, non-Platonic set of answers to Platonic questions to offer, but rather that they do not think we should ask those questions anymore. When they suggest that we not ask questions about the nature of Truth and Goodness,

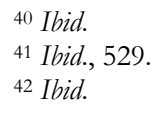


the do not invoke a theory about the nature of reality or knowledge of man which says that "there is no such things" as Truth or goodness. ${ }^{43}$

\section{Rorty's Challenge to Education}

Where education for Plato is the recollection of a truth that has preexisted before us, for Rorty it is a communal enterprise, a process which every individual must be involved in and take responsibility. Truth is shared, and every member of the community should be involved in the process of finding it.

There might not be one truth held by everybody in the community, as there might be more than one community holding on to one truth. Each community may, as our philosopher believes, worship "one hero" - say Einstein, Shakespeare, Freud, or even Plato. In this set-up, the students will see that what they are studying, examining, conceptualizing - comes from a certain tradition, and in that tradition there were people who attempted to solve the problems of their own time; some of them succeeded, others have not. Aristotle for example is one hero in the history of the ancient world who addressed the questions on ethics, human nature, politics, etc. But what we can draw from Aristotle is the lesson, that he made a great and systematic attempt to earnestly and rigorously analyze the problems of his day and their possible solutions. To some extent, he succeeded. His success however has been divinized by many, stretching it too far, and making a set of dogmatic propositions out of it.

For Rorty, hero worship is needed by the educational process. Just because there is no objective truth, does not mean that we have become like that proverbial mosquito inside the bottle who does not know where to move out. There are heroes in every discipline and they tell us what they have done before; for us people of today, the challenge is to identify our own problems and own them by looking up to those who were before us, and then try to communally come up with our own responses and solutions to our problems. There is also a need therefore for disciplines to mutually dialogue each other, but other than this, they must also mutually dialogue with each other. In the greater scheme of things therefore, there cannot just be one hero. Using Nietzsche, Rorty believes, that in the community of today, "the difference between science and literature fades out" such that "[t]he fighters against their time who are our models may include Goethe as well as Galileo, Woodsworth as well as Darwin, Holderlin as well as Marx and Freud."

43 Richard Rorty, "Consequences of Pragmatism," in Marxists Internet Archive $<\underline{\text { http://www2.cddc.vt.edu/marxists/reference/subject/philosophy/works/us/rorty.htm }>, 10}$ March 2010.

44 Rorty, HGST, 531. Here I would like to quote what Rorty says of philosophy, which I think should also be true to the importance of heroes in education despite the rejection beforehand of the notion of an ontologically eternal truth. Thus, "I am all for getting rid of canons which have become merely quaint, but I do not think that we can get along without 
Rorty's philosophy of education sheds light to some of the problems that have been with this country's educational system for quite some time; among these problems is the question concerning the role of the Liberal Arts. ${ }^{45}$ For example, the so-called technical experts and curriculum designers of the country's higher education commission have reduced the number of units of philosophy and the social sciences courses to give way to the growing number of units of their disciplines' major courses (e.g. Engineering, Nursing, etc). One typical case was the merger of two social science courses ${ }^{46}$ in a certain professional curriculum, perhaps on the pretext that some lesson contents of the two disciplines are interchangeable; and with the need to add a few major subjects, then all the more is the move to merge (i.e. the one on political science and history) apparently justified.

Coming from Rorty, the said kind of attitude of our higher-educationexperts; their kind of thinking, develops in our educational system a unitary if not mono-logic discourse that is characterized by lack in critical depth. The country may have been producing graduates who are good in the necessary technical-know-how of the discipline but at the expense of the other domains of knowledge like philosophy and the social sciences. This situation reflects the lack of understanding among some of our so-called "education experts" that the process of education is not the same with the process of canning tunas in factories. The whole process is not just about the production of technically good engineers, architects, and accountants. It is also about them as being part of a system, which is by nature intellectual, social, and political - culturally and historically bound by certain ideals. ${ }^{47}$

An educational system that merely produces people with good technical know-how and nothing more, would end up simply having human resources who may be scientific in the naturalist and materialist sense of the terms, but wanting in the other aspects of human life; people so heavily influenced by the homogenous scientific training might even be antagonistic, or to say the least negative in perception to the humanities, which for them are inferior in method. Our universities may produce Communication and Linguistics graduates who are good in verbal gymnastics but, beyond which, (are) lacking in analytic depth, impoverished in terms of social awareness, and

canons. This is because we cannot get along without heroes. We need mountain peaks to look up towards. We need to tell ourselves detailed stories about the mighty dead in order to make our hopes of surpassing them concrete." Cf. Richard Rorty, "The Historiography of Philosophy: Four Genres," Philosophy in History, ed. Richard Rorty and others (Cambridge: Cambridge University Press, 1984), 73. Philippines

45 This part of the discussion refers to the situation and condition of education in the

46 The courses being referred to are Political Science and History.

${ }^{47}$ I think no official of DepEd or CHED, who has sworn oath before the President of the Republic (the head of State), thinks that education is not for the State. Any official who believes or thinks that we educate people not for the State but for something else, might just be too ridiculous in flippantly thinking that we are in some condition of life similar to that of Mel Gibson's Mad-max, i.e. state-less. 
inadequate in terms of political facts. The output that this over-all situation yields is one where there is a constellation of individuals who know much of a few; where each stands on his own existential space without any realization of his significance in the greater scheme of things. This kind of situation reminds us, according to Rorty, that "[c]ritical thinking is playing off alternatives against one another, rather than playing them off against criteria of rationality, much less against eternal verities."

Rorty's philosophy of education is one which privileges the process that the community undergoes in search for truth rather than the claim that there is an objective truth the consequence of which is the marginalization of the voices of many groups, and the devastation of minority groups (e.g. disciplines, cultures). It looks at education as a community activity where both humanistic and scientific camps come into the fore not in order to launch some unilateral critique against each other. Not any unilateral critique, because science nor any specific discipline, does not enjoy any privileged cognitive status over and above the humanities and vice-versa. In this sense, education is now a space other than being a mere process where disciplines meet and evaluate each other, without obliterating tradition, but instead mindful of the need to create a community. In the very words Rorty used to explain his point:

We do not lift ourselves out of history by doing laboratory experiments any more than by reading St. Thomas - we merely, with luck, get some new suggestions about how to solve our problems. This means that neither education in science nor education in the humanities has any claim to centrality. ${ }^{49}$

\section{Conclusion}

When Rorty debated with the critical theorist Jurgen Habermas and the Marxist Leszek Kolakowski on the state of philosophy, particularly on the topic, the "challenge of relativism" - the American pragmatist shared with wit his understanding of truth this way:

I take Platonsim and Greek thought generally to say, [t]he set of candidates for truth is already here, and all the reasons which might be given for or against their truth are also already here; all that remains to argue the matter out. I think of romantic ... hope as saying, [s]ome day all

${ }^{48}$ For this assessment to be fair, I also would like to believe that those in the liberal arts must try to reach out and apply their oftentimes abstract concepts to the actual and practical sphere. This way, their theories could be validated. For example those disciplines that are into policy studies (e.g. Political Science) should also see to it that the environmental policies are scientifically informed.

${ }^{49}$ Rorty, HGST, 529. 
of these truth candidates, and of these notions of what counts as a good reason for believing them, may be obsolete; for a much better world is to come-one in which we shall have wonderful new truth candidates. ${ }^{50}$

If there is no absolute truth, if there are no eternal values fixed by some unquestionable essences, then what's our destiny, what face of humanity are we going to create? Rorty's answer (I think) would be: that is "the task of education." This is what the opening statement, of this essay, in its depth profoundly means, that the search for truth is the search for the widest possible inter-subjective agreement.

Department of Political Science, University of San Carlos, Philippines

\section{References}

Cahn, Steven M., Classic and Contemporary Reading in Pbilosophy of Education (New York: McGraw-Hill Companies, 1997).

Dewey, John, "Democracy and Education" (selection) in Classic and Contemporary Reading in Philosophy of Education," in Steven Cahn, ed. (New York: McGraw-Hill Companies, 1997).

Gadamer, Hans-Georg, Truth and Method (London: Sheed and Ward, 1979).

Guingon, Charles and David Hiley, Richard Rorty (Cambridge: Cambridge University Press, 2003).

Heidegger, Martin, Being and Time, trans. by John Macquarrie and Edward Robinson (New York: Harper and Row, 1962).

Niznik, Josef and John T. Sanders eds., Debating the State of Philosophy: Habermas, Rorty and Kolakowski (Westport, Connecticut: Praeger, 1996).

Quito, Emerita, The Philosophers of Hermeneutics (Manila: De La Salle University Press, 1990).

Rorty, Richard, Philosophy as Cultural Politics: Pbilosopbical Papers, vol. 4 (Cambridge: Cambridge University Press, 2007). Pbilosophy of Social Hope (London: Penguin, 1996). "Hermeneutics, General Studies, and Teaching" in Classic and

Contemporary Reading in Philosophy of Education, ed. Steven Cahn (New York: McGraw-Hill Companies, 1997).

"Does Academic Freedom Have Philosophical Presuppositions: Academic Freedom and the Future of the University," in Academe (Nov.-Dec. 1994).

Contingency, Irony, and Solidarity (New York: Cambridge University Press, 1989).

The Historiography of Philosophy: Four Genres," Philosophy in History, ed. Richard Rorty and others (Cambridge: Cambridge University Press, 1984).

${ }^{50}$ Niznik and Sanders, op cit., 51. 


\section{RORTY'S PHILOSOPHY OF EDUCATION}

"Consequences of Pragmatism." [article online]: Available from: http://www2.cddc.vt.edu/marxists/reference/subject/philosophy/wo rks/us/rorty.htm.

Philosophy and the Mirror of Nature (New Jersey: Princeton University Press, 1979).

Stumpf, Samuel Enoch, Socrates to Sartre: A History of Philosophy, $6^{\text {th }}$ ed. (Boston: McGraw Hill, 1999).

Tartaglia, James, Rorty and the Mirror of Nature (London: Routledge, 2007).

Taylor, Charles, "Rorty and Philosophy" in Charles Guignon and James Hiley, eds., Richard Rorty (Cambridge: Cambridge University Press, 2003).

Weinshimer, Joel, Gadamer's Hermeneutics: A Reading of Truth and Method (New Haven: Yale University Press, 1985).

Villarojo, Dennis, The Ontological Conditions of Understanding: A Study of the Hermenentics of Hans-Georg Gadamer in the Light of the Encyclical Fides et Ratio. Ph.D. Dissertation. Pontificia Universitas Sanctae Crucis, Rome, Italy (2001). 